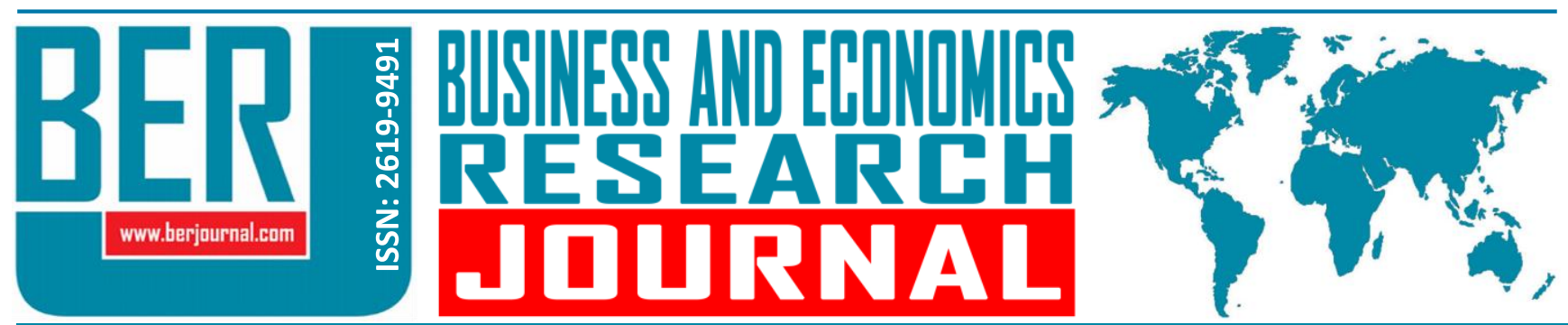

Business and Economics Research Journal Vol. 10, No. 3 Special Issue, 2019, pp. 699-708 doi: 10.20409/berj.2019.194

\title{
Testing the Homogeneity of Non-Adopters of Internet Banking*
}

\section{Berna Serener $^{\mathrm{a}}$}

Abstract: Non-adopters of internet banking is not a homogenous group. In this study, non-adopters are divided into two groups: prospective adopters and persistent nonadopters. The aim of this paper is to analyse how the two non-adopter groups differ with regard to usage, image, tradition, risk and value barriers. Factor analysis is used to categorize the data into five barriers. Independent samples t-tests are used to reveal the differences between prospective adopters and persistent non-adopters of internet banking. The results of this study reveal that persistent non-adopters show more resistance to internet banking in relation to usage, image, tradition, risk and value barriers. The $p$-values indicate that the value barrier differentiates the groups the most, followed by usage, image, risk and tradition barriers. The results highlight the fact that psychological barriers are a greater cause of resistance than functional barriers.
Keywords: Internet banking, Non-adopters, Barriers, Homogeneity

JEL: G21, L81, M31

Received : 05 February 2019

Revised : 05 March 2019

Accepted : 25 March 2019

Type : Research

\section{Introduction}

Adopting internet banking benefit not only banks but customers as well. The number of bank branches and employees decline when banks adopt internet banking. Customers, on the other hand, experience comfortable and convenient banking. Customers, however, are often reluctant to accept internet banking that generates change. Moreover, customers may resist the adoption of internet banking even though it is needed and desirable. Adopting internet banking According to Aboobucker and Bao (2018), perceived risk, trust, usability of websites, privacy and security, age and gender hinder the adoption of internet banking in Sri Lanka. Therefore, understanding the reasons for this resistance is important. Early studies on innovations depicted all innovations as something positive and thus, product improvements were encouraged to succeed and every customer was urged to adopt new innovations (Ram, 1987). Unsurprisingly, in a world where innovations are unquestionably praised, researchers have categorized late adopters of innovation as laggards because of this "pro-innovation bias" (Rogers, 1983).

There are two classes in the innovation diffusion literature. The first group is concerned with the adoption of innovation, whereas the second group concentrates on resistance to innovation by customers (Laukkanen, 2016). Customers resist innovation for two reasons (Sheth, 1981). The first one is related to habit, in that customers are accustomed to using certain products or services and do not feel comfortable with changing habits. The second one is satisfaction, meaning that customers are satisfied with the current products or services they are using. There are different risks associated with adopting an innovation (Laukkanen, Sinkkonen \& Laukkanen, 2009). Physical risk is due to damage caused to a person's belongings, 
whereas economic risks arise when a person adopts an expensive innovation instead of waiting for a better alternative. Functional risks emerge as result of a product malfunctioning. Social risk is related to the fear of becoming socially isolated and rejected by the society. Innovation resistance has three characteristics (Ram \& Sheth, 1989). First, innovation resistance affects the timing of adoption. Laggards show the highest level of resistance, whereas innovators show the least amount of resistance. Second, innovation resistance occurs on a continuum. A passive form of resistance is rejection (Kuisma, Laukkanen \& Hiltunen, 2007). The most powerful form of resistance is rejection. In this case, an innovation is rejected absolutely. An active behavior, on the other hand, is resistance. Resistance may give rise to the adoption or rejection of an innovation. Customers can postpone or delay an innovation either because of situational factors or the complex nature of a product. As a result, customers will search for information and will consequently decide whether to adopt or reject an an innovation. Third, innovation resistance prevails across product classes. Rejection and acceptance can occur together.

Many studies have compared and contrasted non-adopters of internet banking with adopters (Serener, 2017). In these studies, non-adopters of internet banking are treated as a homogenous market. Lee, Kwon and Shumann (2005) argued that the dichotomous categorization of internet users into adopters and non-adopters is often inaccurate, as this kind of categorization ignores the fact that non-adopters are a heterogeneous group. Understanding heterogeneous attributes of internet banking will help the banks to develop strategies for different segments of non-adopters.

African student population is used in this study as Northern Cyprus attracts many African students. The African student population increased from 1,000 in 2010 to 20,000 in 2016 (Hatay, 2017). Morever, Zimbabwean and Nigerian students were more than half of the total African student population in 2016 (Hatay, 2017). The findings of this research will help Cypriot banks to attract African students who are not willing to adopt internet banking.

Studies have been conducted on regulatory frameworks in Nigeria (Eboibi, 2017), the implementation of internet banking services in Nigeria (Charles, 2006), mobile banking and financial inclusion in Africa (Evans, 2018), mobile phones and mobile banks (Oluwatayo, 2013), internet banking regulations in Nigeria (Ezoaha, 2005) and factors affecting the adoption of internet banking in Zimbabwe (Sandada, Somnarashe \& Shamhuyenhanzva, 2016). The barriers preventing internet banking adoption in Zimbabwe and Nigeria have previously been analysed (Serener, 2018); however, non-adopters of internet banking have not been categorized into groups. However, to the best of the authors' knowledge, no studies have segmented the non-adopters of internet banking users in Nigeria and Zimbabwe. Therefore, this article aims to fill this gap in the literature.

In this study, non-adopters of internet banking are divided into two groups: perspective adopters and non-adopters. The aim of this study is to analyse how the two non-adopter groups differ with regard to usage, image, tradition, risk and value barriers.

\section{Theoretical Framework and Literature Review}

\subsection{Theoretical Framework}

Several barriers immobilize the adoption of an innovation (Ram \& Sheth, 1989). These are usage, value, risk, tradition and image barriers (Sheth, 1981). Usage, value and risk are functional barriers. Tradition and image, on the other hand, are psychological barriers. When consumers perceive that adopting an innovation will have a considerable impact on their lives, functional barriers emerge. Psychological barriers happen when the adoption of the innovation clashes with the person's prior beliefs.

Customers oppose the adoption of an innovation when the innovation does not conform with their current practices and routines, and as a result, usage barrier arises. if the "performance-to-price" ratio is not as good as the product the customer is aiming to replace it with then customers will not adopt and innovation and value barrier will arise. Image barrier is due to customers' negative perceptions of a product. When a 
person digresses from accepted norms due to an innovation, tradition barrier arises. Uncertainty involved with an innovation is the risk barrier.

\subsection{Literature Review}

Mobile banking is very popular in Zimbabwe (Oluwatayo, 2013). Economic growth has been positively impacted by the development of mobile networks of telecommunication (Mothobi \& Grzybiwski, 2017). People living in urban areas of Zimbabwe send money to their family members who are living in rural areas of the country. However, transferring cash to villages that are located considerable distances from the cities can be problematic. Mobile banking ( $m$-banking) is therefore beneficial for low-income, unbanked customers in Africa (Chinakidzwa, Mbengo \& Nyatasambo, 2015). It allows users to store and transfer money by using their mobiles and to access financial products. Furthermore, mobile banking connects the poor to financial services, thus leading to financial inclusion (Evans, 2018). In research conducted on the Mudzi district of Zimbabwe, where most citizens do not have convenient access to bank accounts, the inability to maintain a bank account due to the associated costs, the lack of dependable income and distances to banks were cited as the major reasons for using mobile money. The study findings revealed that $65 \%$ of citizens used mobile money as it provided a cheap substitute for banks (Chinakidzwa et al., 2015). Mobile money agents help the unbanked customers living in isolated places where there are no banks or a lack of infrastructure for telecommunication connection. In such an environment, despite the convenience internet banking provides to customers, the adoption of such services has been slow in Zimbabwe. Thulani (2009) posits that internet banking adoption has been slow in Zimbabwe due to perceived risk, lack of rules and regulations and high cost of implementation.

In a study conducted in Nigeria (Agboola, 2006), it was found that slow economic development, inefficient telephone service providers, illegal activities and insufficient facilities for internet banking are some of the barriers preventing the implementation of internet banking in the country. Chiemeke, Evwiekpaefe, and Chute (2006), on the other hand, argued that the lack of reliable telecommunications infrastructure and power were the main reasons preventing the adoption of internet banking in Nigeria. Nigeria has a reputation for high levels of internet fraud. According to Adommi and Igun (2008), "ease of access to the internet", "anonymity offered by the internet", "availability of e-mail extractor software/sites on the internet", "ignorance of the gravity of breaking the law online", "economic conditions of the people", and "inadequate law enforcement are the main reasons for cybercrime in Nigeria. The Crime Complaint Center (IC3) reported that Nigeria was the third country globally and the first country in Africa in terms of the number of complaints received for cybercrime penetration (Eboibi, 2017). In an effort to protect the banks from the risks of fraud, the Nigerian Cybercrimes Act of 2015 was passed. Citizens are now penalized for online fraud, computer-related fraud and forgery of electronic signatures (Eboibi, 2017). Embezzlement, money laundering, internet fraud, and abuse by business insiders are alarming concerns affecting the Nigerian banking system (Ezeoha, 2006). Furthermore, corruption coupled with unemployment, poverty and poor management is eroding the public confidence.

Numerous articles have analyzed consumers' resistance to internet banking (Ellen, Bearden \& Sharma, 1991; Sathye, 1999; Rotchanakitumnuai \& Speece, 2003; White \& Nteli, 2004; Gerrard, Cunningham \& Devlin, 2006, Kuisma et al., 2007). Kuisma et al. (2007) interviewed 30 Finnish customers and their results indicated that not only functional but also psychological barriers are the factors contributing to the resistance of internet banking adoption. In a study involving corporate customers in Thai banks, internet security was revealed to be the most important element inhibiting internet baking adoption (Rotchanakitumnuai et al., 2003). Non-adopters had less trust in the financial transactions completed via the internet compared to adopters. Furthermore, corporate customers claimed that no effective judicial system was in place that protected internet banking users. Although the number of internet users is growing, the number of users engaging in internet banking is falling behind (White \& Nteli, 2004). The most prominent reason in the UK was found to be concerns over security (White \& Nteli, 2004). In Singapore, in a study conducted on 127 nonusers of internet banking, "perceived risk", "lack of perceived need", "inadequate knowledge", "resistance to change", "unavailability", "lack of human touch", "pricing" and "IT fatigue" were found to be the reasons 
for not adopting internet banking (Gerrard et al., 2006). Ellen et al. (1991) on the other hand, claimed that the lack of self-efficacy and performance fulfillment with the services prevents the users from utilizing internet banking.

Only a limited number of studies have attempted to segment the non-adopters of product innovation. Rogers (1983) segmented the innovators into five groups: innovators, early adopters, early majority, late majority and laggards.

In another study, three different types of innovation resistance faced by credit and debit card users were identified: rejection, postponement and opposition (Szmigin \& Foxall, 1998). When consumers reject an innovation, the company is required to make a completely new product or make partial changes. Procrastinators may postpone an innovation because of situational factors. In this instance, some consumers will be willing to try the product at some time in the future. Some other consumers, on the other hand, will be incapable of trying the product because they have only symbolically adopted the product. Those consumers who are opposed to the product may test and then reject the innovation. The study concluded that innovation resistance should not be perceived as unfavorable feature of consumers, but managers should use this information to understand the customers with the aim of launching successful, new products in the future (Szmigin \& Foxall, 1998).

In a study conducted in Tunisia, 150 non-adopters of internet banking were divided into three groups: postponers, opponents and rejectors (Brahim, 2015). The authors posited that functional barriers have no effect on the refusal to accept internet banking, while these three groups of non-adopters were dissimilar in terms of psychological barriers. In Egypt (Elbadrawy \& Aziz, 2011) significant differences were found among postponers, opponents and rejectors in relation to image, value and usage barriers. On the contrary, with respect to risk and tradition barriers, postponers, opponents and rejectors did not differ.

Lee et al. (2005) segmented non-adopters into two groups named persistent non-adopters and prospective adopters. Respondents who were willing to open an internet bank account during the following year were classified as prospective adopters, whereas respondents who were not willing to open an internet banking account during the next year were grouped as persistent non-adopters. The authors posited that there were significant differences between the two categories non-adopters.

In a study performed on Finnish non-adopters of internet banking, customers were divided into three groups: postponers, opponents and rejectors (Laukkanen, Sinkkonen \& Laukkanen, 2008). The differences in these groups with respect to usage barrier, value barrier, risk barrier, tradition barrier and image barrier were analyzed. Significant differences were found among postponers, opponents and rejectors in terms of usage, value, tradition and image barriers. However, there were no significant differences among these three groups in terms of the risk barrier. Rejectors showed the highest amount of rejection, whereas postponers showed the least amount.

\section{Methodology and Data}

\subsection{Hypothesis Development}

Following Laukkanen et al. (2008) and Kuisma et al. (2007), internet banking barriers are used in this study.

\subsubsection{Usage Barrier}

Changing habits and practices can be a lengthy and frustrating process. In the TAM (Technology Acceptance Model) model, usage barrier refers to ease-of-use (Davis, 1989) which means that an innovative product is used without any struggle. The perceived ease-of-use and intention to use internet banking are directly related to each other. According to Rogers (1983), this idea is related to the notion of complexity. If customers find using internet banking complex and troublesome, they will avoid using it. Thus, we hypothesize that: 
H1: Usage barrier is higher among persistent non-adopters compared to prospective adopters.

\subsubsection{Value Barrier}

If a customer does not see the monetary value or how well a product can function, then he/she will not use the product. In Rogers' (2003) world, value is related to the notion of relative advantage. In the TAM literature, value is represented by the concept of perceived usefulness. If a customer feels that using internet banking does not offer a relative advantage compared to visiting a branch, then internet banking will not be used. If a customer feels that by using internet banking, he/she will take matters into his/her own hands, then he/she will prefer internet banking. Therefore, we propose that

$\mathrm{H} 2$ : Value barrier is higher among persistent non-adopters compared to prospective adopters.

\subsubsection{Image Barrier}

An innovation possesses a certain uniqueness from its inception based on the country, the product class and the industry to which it belongs. If any of these relationships are disadvantageous, then the internet banking will face an image barrier. If the customers' perceptions of computers are that they are difficult to use, they will refuse to use internet banking. This barrier is related to customers feeling uneasy about using computers and having pessimistic perceptions about using new technology. Thus, we hypothesize that:

H3: Image barrier is higher among persistent non-adopters compared to prospective adopters

\subsubsection{Tradition Barrier}

If the innovation requires a person to digress from accepted norms, it will be opposed. The greater the discrepancy is, the greater the refusal to accept the innovation. People have routines and innovation may alter these routines. For instance, customers may be accustomed to visiting a branch and speaking directly to a teller. When social contacts are important, adopting internet banking will be refused as it lacks human interaction. Thus, we propose that,

H4: Tradition barrier is higher among persistent non adopters compared to prospective adopters

\subsubsection{Risk Barrier}

There is always uncertainty involved with an innovation and the repercussions of the risks usually cannot be predicted. Security and privacy are common concerns among the non-adopters of internet banking. Security pertains to the panic a customer might feel caused by the fear they might lose their money when using internet banking. Privacy is related to the management of personal information in an ethically acceptable way. Customers perceive internet banking to be risky because of several reasons. For example, customers may be afraid that their connection will be lost when engaging in internet banking. The lack of documentation proving a transaction has been completed is also a risk. The fear of a cybercriminal accessing one's bank account is a perceived risk. Increased anxiety of losing the list of pin codes imposes a risk. The higher the risk, the lower the internet banking adoption. Thus, we propose that,

H5: Risk is not higher among persistent non-adopters compared to prospective adopters

\subsection{Survey Design}

A questionnaire containing 14 questions was adopted from different sources. Table 1 shows the sources of the questions. The scale used was a seven-point Likert-type ranging from "strongly disagree $=1$ " to "strongly agree=7". Following Lee et al. (2005), respondents were asked if they were willing to adopt internet banking within the next 12 months. Respondents who answered "somewhat likely" or "likely" or "very likely were grouped as prospective adopters. Respondents who answered "very unlikely" or "unlikely" or "somewhat unlikely" were grouped as persistent non-adopters. 


\subsection{Data Collection}

A total of 150 undergraduate students from a private university in Northern Cyprus were interviewed. In terms of nationality, 75 students were Nigerians and 75 were Zimbabweans. Fifty percent of the students were males and fifty percent were females. Average age of the respondents were 20 . Survey was conducted by getting random samples of 38 freshmen, 38 sophomores, 37 juniors and 37 seniors.

\section{Empirical Analysis}

\subsection{Factor Analysis}

Factor analysis is considered appropriate in this study as similar studies used factor analysis to categorize different barrier of internet banking usage. (Laukkanen, 2010; Lukkanen et al., 2008). Data was categorized into 5 barriers by using factor analysis (Table1). Total variance explained was $77.667 \%$. The Cronbach's alpha values measuring reliability were acceptable. The values were between 0.762 and 0.867 . The sampling adequacy measure of Kaiser-Meyer-Olkin (KMO) was 0.9. The data was suitable for factor analysis as the Bartlett's test of sphericity had a significant value at $p=0.00$.

\subsection{Independent Samples T-Tests}

Independent samples t-tests were used to reveal the differences between prospective adopters and persistent non-adopters of internet banking. Average values of usage, image, tradition, risk and value barriers are higher for persistent non-adopters than prospective adopter. It is shown in Table 2 that the two nonadopter groups stand apart significantly in terms of the usage $(p=0.030)$, value $(p=0.041)$, tradition $(p=0.092)$, risk $(p=0.073)$ and value barriers $(p=0.019)$. Our results indicate that prospective non-adopters showed low resistance compared to persistent non-adopters. Therefore, hypotheses $\mathrm{H1}, \mathrm{H} 2, \mathrm{H} 3, \mathrm{H} 4$ and $\mathrm{H} 5$ are accepted.

The tradition barrier received the highest mean (5.56) followed by risk (mean=5.54), image ( $m e a n=4.43)$, value (mean=2.72) and usage (mean=1.94) barriers among prospective adopters and persistent non-adopters. Thus, the tradition barrier is the most powerful barrier followed by the risk, image, value and usage barriers (Table 2).

Table 1. Measure Items of the Study

\begin{tabular}{|c|c|c|c|}
\hline Measure Items & $\begin{array}{l}\text { Factor } \\
\text { loading }\end{array}$ & $\begin{array}{l}\text { Cronbach's } \\
\text { alpha } \\
\alpha \text {-value }\end{array}$ & $\begin{array}{l}\text { Internet Banking } \\
\text { Literature }\end{array}$ \\
\hline Usage barrier & & 0.844 & \\
\hline I can adapt to new computer-based services (-) & 0.879 & & Hughes, Patsiotis and \\
\hline I feel comfortable with technology-enabled services (-) & 0.868 & & Weber (2013). \\
\hline I have a well-developed ability to operate a computer (-) & 0.830 & & \\
\hline Image barrier & & 0.867 & \\
\hline $\begin{array}{l}\text { I have such an image that internet banking services are } \\
\text { difficult to use }\end{array}$ & 0.864 & & $\begin{array}{l}\text { Laukkanen, et al. } \\
\text { (2009) }\end{array}$ \\
\hline I find technology-enabled services complicated to use. & 0.854 & & \\
\hline $\begin{array}{l}\text { In my opinion, new technology is often too complicated } \\
\text { to be useful }\end{array}$ & 0.812 & & \\
\hline Tradition barrier & & 0.805 & \\
\hline $\begin{array}{l}\text { I prefer to deal face to face with the bank's customer } \\
\text { services department }\end{array}$ & 0.875 & & Hughes et al. (2013) \\
\hline $\begin{array}{l}\text { I prefer face-to-face contact to explain what I want and } \\
\text { to be given answers to my questions }\end{array}$ & 0.783 & & \\
\hline $\begin{array}{l}\text { I like to communicate with people when financial } \\
\text { services are being provided }\end{array}$ & 0.731 & & \\
\hline Risk barrier & & 0.762 & \\
\hline
\end{tabular}


Table 1. Measure Items of the Study (Continued)

\begin{tabular}{|c|c|c|c|}
\hline Measure Items & $\begin{array}{l}\text { Factor } \\
\text { loading }\end{array}$ & $\begin{array}{l}\text { Cronbach's } \\
\text { alpha } \\
\alpha \text { - value }\end{array}$ & $\begin{array}{l}\text { Internet Banking } \\
\text { Literature }\end{array}$ \\
\hline $\begin{array}{l}\text { I am concerned that third parties may track my banking } \\
\text { patterns }\end{array}$ & 0.824 & & Hughes et al. (2013) \\
\hline $\begin{array}{l}\text { I am concerned that third parties may be able to access } \\
\text { my financial details. }\end{array}$ & 0.778 & & \\
\hline $\begin{array}{l}\text { My expectations of losing money as a result of using } \\
\text { internet banking are high }\end{array}$ & 0.770 & & \\
\hline Value barrier & & 0.820 & \\
\hline $\begin{array}{l}\text { Using internet banking would make my transactions } \\
\text { easier (-) }\end{array}$ & 0.890 & & $\begin{array}{l}\text { Hughes et al. (2013) } \\
\text { and Chong, Ooi, Lin and }\end{array}$ \\
\hline Internet banking would increase my productivity (-) & 0.888 & & $\operatorname{Tan}(2010)$ \\
\hline Total cumulative variance explained & $77.667 \%$ & & \\
\hline
\end{tabular}

Note: (-) Reversed scale

The $p$-values indicate that the value barrier $(p=0.019)$ differentiated prospective adopters and persistent non-adopters most, followed by the usage $(p=0.030)$, image $(p=0.041)$, risk $(p=0.073)$ and tradition barriers ( $p=0.092)$. Moreover, the results highlight the fact that psychological barriers are a greater cause of resistance than functional barriers (Table 3 ).

Table 2. A Comparison of Prospective Adopters and Persistent Non-adopters

\begin{tabular}{lllll}
\hline \multirow{2}{*}{ Measure Items } & \multicolumn{3}{c}{ Mean Values (Standard Deviation) } & \\
\cline { 2 - 4 } & $\begin{array}{l}\text { Prospective } \\
\text { Adopters }\end{array}$ & $\begin{array}{l}\text { Persistent Non- } \\
\text { adopters }\end{array}$ & Total & $\begin{array}{l}\text { Significance } \\
\text { (p-value) }\end{array}$ \\
\hline Usage barrier & $1.62(0.59)$ & $2.51(1.40)$ & $1.94(1.04)$ & $0.030^{* *}$ \\
Image barrier & $3.64(1.62)$ & $4.88(1.90)$ & $4.43(1.88)$ & $0.041^{* *}$ \\
Tradition barrier & $5.00(1.76)$ & $5.88(1.05)$ & $5.56(1.40)$ & $0.092^{*}$ \\
Risk barrier & $4.96(1.76)$ & $5.87(0.77)$ & $5.54(1.29)$ & $0.073^{*}$ \\
Value barrier & $2.33(0.88)$ & $3.40(1.48)$ & $2.72(1.24)$ & $0.019^{* *}$ \\
\hline
\end{tabular}

$1=$ totally disagree; $7=$ totally agree

${ }^{*} \mathrm{p}<0.10 ;{ }^{* *} \mathrm{p}<0.05 ;{ }^{* * *} \mathrm{p}<0.01$

Table 3. Functional and Psychological Barriers of Propective Adopters and Persistent Non-adopters

\begin{tabular}{llll}
\hline & \multicolumn{3}{c}{ Mean Values (Standard Deviation) } \\
\cline { 2 - 4 } & $\begin{array}{l}\text { Prospective } \\
\text { adopters }\end{array}$ & $\begin{array}{l}\text { Persistent non- } \\
\text { adopters }\end{array}$ & Total \\
\hline $\begin{array}{l}\text { Functional } \\
\text { barriers }\end{array}$ & $3.27(0.43)$ & $3.62(0.95)$ & $3.40(0.68)$ \\
$\begin{array}{l}\text { Psychological } \\
\text { barriers }\end{array}$ & $4.32(1.26)$ & $5.38(1.37)$ & $5.00(1.41)$ \\
\hline \begin{tabular}{l} 
1= totally disagree; 7 = totally agree \\
\hline
\end{tabular}
\end{tabular}

\section{Results and Discussion}

Our results revealed that usage, image, tradition, risk and value barriers are significantly different for prospective adopters and persistent non-adopters. Thus, segmenting adopters and non-adopters of internet banking into two groups lacks sophistication as non-adopters do not form a homogenous group. Except for the risk barrier, our results are in harmony with those presented by Luakkanen et al. (2008) and Lee et al. (2005). Luakkanen et al. (2008) and Lee et al. (2005) did not find any significant differences among non- 
adopter groups in terms of perceived risk. Elbadrawy and Aziz (2011) did not report any differences among non-adopters of internet banking in terms of tradition; therefore, our results are different from those of Elbadrawy and Aziz's (2011).

Our results indicate that psychological barriers are a stronger impediment than functional barriers. This is similar to Luakkanen et al.'s (2008) results. The greatest inhibitor of internet banking for both prospective adopters and persistent non-adopters is the tradition barrier. Contrary to our results, Laukkanen (2016) reported the value barrier as the most powerful inhibitor, whereas Laukkanen et al. (2008) indicated that the perceived risk barrier was the most powerful impediment of internet banking.

\section{Conclusions and Managerial Implications}

The results of this study reveal that persistent non-adopters show more resistance to internet banking in relation to usage, image, tradition, risk and value barriers. The value barrier differentiates the groups the most, followed by usage, image, risk and tradition barriers. The results highlight the fact that psychological barriers are a greater cause of resistance than functional barriers. Therefore, prospective adopters and persistent non-adopters are two different segments.

Banks in Nigeria and Zimbabwe should formulate different strategies for these two groups. The greatest discrepancies between these two groups are in the value and the usage barriers. In other words, persistent non-adopters do not find internet banking to be easy to use or useful. The value barrier can be reduced by improving the internet banking service offered by banks. In order to decrease the value barrier, Nigerian and Zimbabwean banks need to promote the beneficial aspects and value of internet banking. Different services offered through internet banking should be advertised. Moreover, by making internet banking cheaper compared to using physical banking services, banks can reduce the value barrier. For instance, fees may be charged for visiting a branch in order to encourage the use of internet banking. According to Laukkanen and Kiviniemi (2005), the information and guidance provided by the banks have the greatest impact on lowering the usage barrier. Therefore, the banks have to provide advice and direction on internet banking.

In order to fight the resistance of non-adopters of internet banking, Ram (1989) suggested that communication strategies can be implemented, which he arranged into two classes. One dimension shows how much a bank (marketer) can control the innovation. The second dimension shows the kind of influence the communication method has on the user. In this article, we will concentrate on the communication methods controlled by the bank. According to Ram (1989), "change agents", "mass media", "publicity releases" and "testimonials" are the communication strategies that are highly controlled by the marketer. Laukkenen et al. (2009) suggested communication strategies to overcome functional barriers. Banks need to educate their customers on a one-to-one basis in bank branches. Banks should emphasize the practicality and ease of use aspects of internet banking to their customers. The merits of internet banking should be highlighted while marketing the services. Technical support should be made available 24 hours a day for those customers who do not feel comfortable with using internet banking. In branches, customers should have the ability to try internet banking. Triability will decrease the perceived risk and thus the resistance to internet banking. Banks can raise service fees for in-branch services in order to make going in to branches less attractive.

Banks need to use communication strategies to decrease the psychological barriers. Branch employees can act as "change agents" to cross-sell internet banking to those customers who are visiting branches. Face-to-face communication will lead to an assured, optimistic and distinct image of internet banking. Mass media communication using newspapers, magazines, radio, television and internet should be used to boost the image of internet banking users. The image barrier can be overcome by running advertisements that emphasise the inefficiency of those who waste time by visiting a branch. Customers often feel that internet banking lacks human interaction. Internet banking services can be customized by adding a welcome message with the individual's name. 


\section{Limitations and Further Research}

Needless to say, this study has certain limitations. First, the study ignored demographic variables such as age, gender, employment and income. Dividing the data into social classes could have produced different results. Second, the sample size was only 150 students. An average customer might behave in a different manner to a student. Thus, this research can be repeated with an increased sample size and people from all age groups can be included in the future. Third, this study divided the non-adopters of internet banking into prospective adopters and persistent non-adopters. In future studies, non-adopters of internet banking can be divided onto postponers, opponents and rejectors.

\section{End Notes}

* This study was presented in "IV. International Conference on Applied Economics and Finance \& Extended with Social Sciences (ICOAEF'18)" that organized in 28-29-30 November 2018 and the abstract was published in the Book of Abstract Proceeding.

\section{References}

Aboobucker, I., \& Bao, Y. (2018). What obstruct customer acceptance of internet banking? Security and privacy, risk, trust and website usability and the role of moderators. The Journal of High Technology Management Research, 29(1), 109-123.

Adomi, E. E., \& Igun, S. E. (2008). Combating cybercrime in Nigeria. The Electronic Library, 26(5), 716-725.

Agboola, A. A. (2006). Electronic payment systems and tele-baking services in Nigeria. Journal of Internet Banking and Commerce, 11(3), 1-7.

Brahim, S. B. (2015). Typology of resistance to e banking adoption by Tunisia. Journal of Electronic Banking Systems, 2015(2015). 1-8.

Charles, A. (2006). The prospects of e-commerce implementation in Nigeria. Journal of Internet Banking and Commerce, 11(3), 2006, 1-7.

Chinakidzwa, M., Mbengo, P., \& Nyatsambo, M. (2015). Mobile money usage in rural areas of Zimbabwe- case of Mudzi District. International Journal of Scientific \& Engineering Research, 6(2), 128-132.

Chiemeke, S. C., Evwiekpaefe, A. E. \& Chete, F. O. (2006). The adoption of internet banking in Nigeria: An empirical investigation. Journal of Internet Banking and Commerce, 11(3), 1-9.

Chong, A. Y. L., Ooi, K. B., Lin, B. \& Tan, B. I. (2010). Online banking adoption: An empirical analysis. International Journal of Bank Marketing, 28 (4), 267-287.

Davis, F. D. (1989), Perceived usefulness, perceived ease of use, and user acceptance of information technology. MIS Quarterly, 13(3), 319-40.

Eboibo, F. E. (2017). A review of the legal and regulatory frameworks of Nigerian Cybercrimes Act 2015. Computer Law and Security Review, 33(5), 700-717.

Elbadrawy, R., \& Aziz, R. A. (2011). Resistance to mobile banking adoption in Egypt: A cultural Perspective. International Journal of Managing Information Technology, 3(4), 9-21.

Ellen, P. S., Bearden, W. O., \& Sharma, S. (1991). Resistance to technological innovations: An examination of the role of self-efficacy and performance satisfaction. Journal of the Academy of Marketing Science, 19(4), 297-307.

Evans, O. (2018). Connecting the poor: The internet, mobile phones and financial inclusion in Africa. Digital Policy, Regulation and Governance, 20(60), 568-581.

Ezeoha, A. E. (2005). Regulating internet banking in Nigeria: Problems and challenges -Part 1. Journal of Internet Banking and Commerce, 10(3), 1-5.

Ezeoha, A. E. (2006). Regulating internet banking in Nigeria: Some success prescriptions -Part 2. Journal of Internet Banking and Commerce, 11(1), 1-12.

Gerrard, P., Cunningham, J. B. \& Devlin, J. F. (2006). Why consumers are not using internet banking: A qualitative study. Journal o Services Marketing, 20(3), 160-168. 
G. Patsiotis, A., Hughes, T., \& J. Webber, D. (2013). An examination of consumers' resistance to computer-based technologies. Journal of Services Marketing, 27(4), 294-311.

Hatay, M. (2017, 9 November). Üniversite sektörü ve Akrikalı öğrenciler. Havadis. Retrieved from https://www.havadiskibris.com/

Joachim, V., Spieth, P., \& Heidenreich, S. (2018). Active innovation resistance: An empirical study on functional and psychological barriers to innovation adoption in different contexts. Industrial Marketing Management, 7, 95-107.

Kuisma, T., \& Laukkanen, T., \& Hiltunen, M. (2007). Mapping the reasons for resistance to internet banking: A meansend approach. International Journal of Information Management, 27(2), 75-85.

Laukkanen, P., Sinkkonen, S., \& Kaukkanen, T. (2008). Consumer resistance to internet banking: Postponers, opponents and rejectors. The International Journal of Bank Marketing, 26(6), 440-455.

Laukkanen, T. (2016). Consumer adoption versus rejection decisions is seemingly similar service innovations: The case of the Internet and mobile banking. Journal of Business Research, 69, 2432-2439.

Laukkanen, T., \& Kiviniemi, V. (2010). The role of information in mobile banking resistance. International Journal of Bank Marketing, 28(5). 372-388.

Laukkanen, T., Siekkinen, S., \& Laukkanen, P. (2009). Communication strategies to overcome functional and psychological resistance to internet banking. International Journal of Information Management, 29(2), 111-118.

Lee, E. J., Kwon, K. N., \& Schumann, D. W. (2005). Segmenting the non-adopter category in the diffusion of internet banking. International Journal of Bank Marketing, 23(5), 414-437.

Mothobi, O., \& Grzybowski, L. (2017). Infrastructure deficiencies and adoption of mobile money in Sub-Saharan Africa. Information Economics and Policy, 40(C), 71-79.

Oluwatayo, I. (2013). Banking the unbanked in rural southwest Nigeria: Showcasing mobile phones as mobile banks among farming households. Journal of Financial Services Marketing, 18(1), 65-73.

Ram, S. (1989). Successful innovation using strategies to reduce consumer resistance: An empirical test. Journal of Product Innovation Management, 6(2), 20-34.

Ram, S. (1987). A model of innovation resistance. Advances in Consumer Research, 14(1), 208-212.

Ram, S., \& Sheth, J. N. (1989). Consumer resistance to innovations: The marketing problem and its solutions. The Journal of Consumer Marketing, 6(2), 5-14.

Rogers, E. (2003). Diffusion of innovations ( $5^{\text {th }}$ ed.). New York: Free Press

Rotchanakitumnuai, S., \& Speece, M. (2003). Barriers to internet banking adoption: a qualitative study among corporate customers in Thailand. International Journal of Bank Marketing, 21(6/7), 312-323.

Sandada, M., Simbarashe, N., \& Shamhuyenhanzva, R. (2016). Determining the impact of selected success factors on the adoption of e-banking in the Zimbabwean banking industry. Euro Economica, 35(2), 1-21.

Sathye, M. (1999). Adoption of internet banking by Australian consumers. International Journal of Bank Marketing, 17(7), 324-334.

Serener, B. (2018). Barriers to the use of internet banking among Nigerian and Zimbabwean students in Northern Cyprus. Journal of Management and Economic Research, 16(Special Issue 1), 347-357.

Serener, B. (2017). Internet banking usage in Northern Cyprus: Adopters versus Non-adopters. Ponte, 72(1), 116-126.

Sheth, J. N. (1981). Psychology of innovation resistance: The less developed concept (LDC) in diffusion research. Research in Marketing, 4(3), 273-282.

Szmigin, I., \& Foxall, G. (1998). Three forms of innovation resistance: The case of retail payment methods. Technovation, 18(6/7), 459-468.

Thulani, D. (2009). Adoption and use of internet banking in Zimbabwe: An exploratory study. Journal of Internet Banking and Commerce, 14(1), 1-13.

White, H., \& Nteli, F. (2004). Internet banking in the UK: Why are there not more customers? Journal of Financial Services Marketing, 9(1), 49-56. 